\title{
Evaluation of the Driver's Physiology on Time Pressure situation
}

\author{
Tota Mizuno Member (Aoyama Gakuin University, mizuno@biel.ee.aoyama.ac.jp) \\ Akio Nozawa Member (Meisei University, akio@ee.meisei-u.ac.jp) \\ Hisaya Tanaka Member (Kogakuin University, hisaya@cc.kogakuin.ac.jp) \\ Hideto Ide Member (Aoyama Gakuin University, ide@ee.aoyama.ac.jp)
}

Keywords: Physiological measuremant, Human error, Driver, Time pressure stiuation

There is human error as a common factor of many traffic accidents. There is the work under the time pressure situation as a main cause of human error. It is often that human feel stress with time pressure, this has an influence on a human information processing process. As a result it is thought to lack in grasp of the situation and safe consideration, a logical thought. To deal with human error, the necessity of "prevention security model technology" is pointed out, that the system as early as possible prevents the movement to latent dangerous state by introducing the technology detects a non-normal state and promotes return to a normal state and the system which helps situation recognition together. Therefore, it is the important problem from the viewpoint of "prevention security model technology" to grasp physiology psychological condition of a driver objectivity and fixed-quantity. This study is aimed at evaluate from a nasal skin thermogram measured with an infrared thermography device about a change of physiology psychological condition of a driver. We measured a time change of difference of temperature of frontlet skin temperature and nasal skin temperature that can measure condition of sympathetic system / parasympathetic system indirectly with the infrared

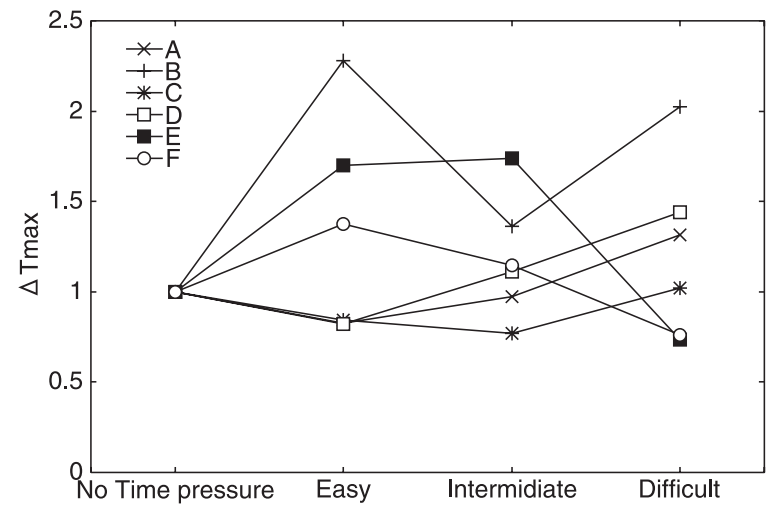

Fig. 1. A $\Delta$ Tmax rate of change thermography device which can measure in non-contact, low restraint, easily.

The experiment measured quantity of physiology from brain waves, a heartbeat, an nasal skin thermogram with the driving simulation problem which made a limit for a driver in time. By performing comparison with quantity of subjectivity, quantity of meandering and driving action quantity and steerage corners to acquire at the same time, we evaluate physiology psychological condition of a driver at the time of driving under the time pressure situation.

As a result, by giving time pressure, difference of temperature of frontlet skin temperature and nasal skin temperature showed a change. Greatest temperature displacement became big when raised a degree of difficulty of time pressure. We understood that stress by time pressure had an influence on autonomic nervous system activity. In addition, high correlation was examined in a rate of change of greatest temperature displacement and an irritation degree. From the above, in evaluation of influence by time pressure and collision of a running driver by a now experiment, it was suggested that quantity of physiology to be provided with a face skin thermogram was effective.

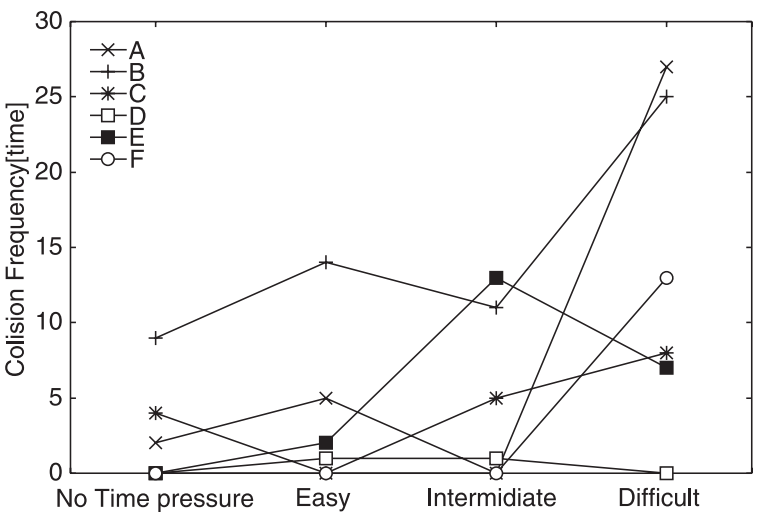

Fig. 2. Collision frequency in each task 


\title{
時間的圧迫下での運転者の生理計測
}

\author{
正 員 水野 統太* 正 員 野澤 昭雄** \\ 正員田中 久弥 ${ }^{* *}$ 正員 井出 英人*
}

\section{Evaluation of the Driver's Physiology on Time Pressure Situation}

Tota Mizuno*, Member, Akio Nozawa**, Member, Hisaya Tanaka***, Member, Hideto Ide*, Member

There is human error as a common factor of many traffic accidents. This study is aimed at evaluate from a nasal skin thermogram measured with an infrared thermography device about a change of physiology psychological condition of a driver. We measured a time change of difference of temperature of frontlet skin temperature and nasal skin temperature that can measure condition of sympathetic system / parasympathetic system indirectly with the infrared thermography device which can measure in non-contact, low restraint, easily. The experiment measured quantity of physiology from brain waves, a heartbeat, an nasal skin thermogram with the driving simulation problem which made a limit for a driver in time. By performing comparison with quantity of subjectivity, quantity of meandering and driving action quantity and steerage corners to acquire at the same time, we evaluate physiology psychological condition of a driver at the time of driving under the time pressure situation. As a result, by giving time pressure, difference of temperature of frontlet skin temperature and nasal skin temperature showed a change. Greatest temperature displacement became big when raised a degree of difficulty of time pressure.

キーワード：生理計測, ヒューマンエラー, ドライバ, 時間的圧迫

Keywords: Physiological measuremant, Human error, Driver, Time pressure stiuation

\section{1. はじめに}

平成 17 年中の交通事故発生件数は 93 万 3,828 件で, そ のうち死者数は 6,871 人, 負傷者数は 115 万 6,633 人であっ た。死者数は, 昭和 31 年以来 49 年ぶりに 7 千人を下回っ たが, 発生件数は 6 年連続で 90 万件を超え, 負傷者数は 7 年連続で 100 万人を超えた ${ }^{(1)}$ 。その多くの交通事故の共通 の要因としてヒューマンエラーが挙げられる。ヒューマン エラーとは，達成しようとする目標から意図せずに逸脱し てしまう期待に反した人間行動である ${ }^{(2)}$ 。人間は臨機応変 に柔軟な行動や判断を行っているが，時折，意図通りでは ない判断や行動をしてしまう。公共交通に係るヒューマン

\footnotetext{
* 青山学院大学理工学部 $\bar{\top} 229-8558$ 神奈川県相模原市淵野辺 5-10-1

Faculty of Science and Engineering, Aoyama Gkauin University 5-10-1 Fuchinobe, Sagamihara-shi, Kanagawa, 2298558

** 明星大学理工学部 $=191-8506$ 東京都日野市程久保 2-1-1 Faculty of Science and Engineering, Meisei University 2-11 Hodokubo, hino-shi, Tokyo, 191-8506

*** 工学院大学 $=163-8677$ 東京都新宿区西新宿 1-24-2 Kogakuin University 1-24-2 Nishi-shinjuku, Shinjuku-ku, Tokyo 163-8677
}

エラー事故防止対策委員会発表の最終とりまとめによると, 事故原因の 80 \%がヒューマンエラーとされる ${ }^{(3)}$ 。ヒュー マンエラーの主な原因として時間的圧迫状況下での作業が 挙げられる。人間は時間的圧迫を受けるとストレスを感じ ることが多く, 人間の情報処理過程に影響を及ぼし, 状況 の把握や安全配慮，論理的思考を欠くと考えられている。 ヒューマンエラーに対処する為に, 通常 (正常) からの逸 脱を検出して通常状態への復帰を促したり，人間側の状況 認識（気づき）を支援するシステムをあわせて導入するこ とによって潜在的危険状態への移行をできるだけ早期に防 止する「予防安全型技術」の必要性が指摘されている。し たがって，ドライバの生理心理状態を客観的かつ定量的に 把握することは「予防安全型技術」の観点から重要な課題 である。ドライバの生理心理状態推定に関する検討は主観 量の他に, 脳波, 心拍, 呼吸, 瞬目などの生理量, あるい は, 蛇行量や操舵角などの運転行動量の解析により行われ てきた。主観量には様々な評価方法があるが，いずれも被 験者毎の性格の違いなどが問題となり絶対的な評価を行う ことが困難である。また, 運転作業下の被験者がリアル夕 イムで主観評価課題に取り組むことは難しい。これに対し て生理量は, 運転作業を妨げることなく, 客観的・定量的 
かつ実時間で扱うことが可能であり，脳波，心拍，皮膚温 度等は無意識下の反応も検出することができる。生理量を 計測する機器には接触型と非接触型があるが, 接触型は被 験者に各種センサを装着する必要があり，このことが被験 者に対する精神的・物理的負担となる可能性がある。実車 走行時には, 低拘束・非侵襲・非接触・無意識計測が求め

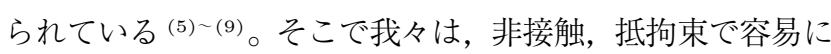
測定することが出来る赤外線サーモグラフィ装置に着目し た。赤外線サーモグラフィ装置は, 人体の皮膚表面から放 射される赤外線の強度を測定し, 温度分布を 2 次元画像と して表示出来るので, 非侵襲かつ非接触計測が可能である 点が大きな特徴である。

一般に, 血流量は生理・心理状態の変化に伴い, 交感神経 系の血管収縮作用を中心とした自律神経活動により変化が 生じる。特に, 鼻部周辺には, 毛細血管の血流量を調整する 動静脈吻合血管 (AVA:Arteriovenous anastomoses) と呼 ばれる動脈と静脈の吻合部（抹消皮膚血管）が集中し，他の 体部位と比較してそれらが多く分布している。さらに，血 管が他の部位では，脂肪層の下を走っているのに対し，鼻部 周辺においては，皮膚と鼻骨のわずかな隙間を走っている。 皮膚温度は血流量の变化に依存するため, 情動ストレスに よる心理状態が鼻部皮膚温度に顕著に現れる。副交感神経 が優勢時には，AVAを通る血流量が増加することとなって 鼻部皮膚温がゆっくりと上昇する。逆に, 交感神経が優勢時 には血流量の減少により温度が短時間に下降する現象が現 れることとなる。このように，一時的な感情の動きで自律 神経や内分泌系などの身体的変化を伴うものを情動といい, 情動を引き起こす因子を情動ストレスと呼ぶ (14)。一方, 前 額部は体幹部に位置し，AVAの密度が低いため自律神経活 動の変化による血流変化が少ない。従って, 前額部皮膚温 と鼻部皮膚温の温度差 (以下，差分温度と記す) の時間的変 化を測定することは，交感神経系・副交感神経系の充進を間 接的に測定することができ，この反応を用いた様々な研究 がなされている ${ }^{(12)(13)}$ 。我々は赤外線サーモグラフィ装置 を用い, 運転中のドライバの顔面熱画像を取得し, するこ とによって, 生理心理状態の評価を行ってきた ${ }^{(11)}$ 。先行研 究では, 運転者の思考と会話両方を伴う課題に起因するメ ンタルワークロードについて, 特に会話形態の違いに関す る影響について赤外線サーモグラフィによる顔面熱画像解 析により検討を行った。結果, 会話形態に関するメンタル ワークロードの変動が, 顔面熱画像を指標として検出され, ドライバ状態の非接触計測法の有効性が示されている ${ }^{(10)}$ 。 そこで本研究は，ヒューマンエラーの主な原因のひとつで ある時間的圧迫状況下でのドライバの生理心理状態の変動 について赤外線サーモグラフイ装置により測定した鼻部熱 画像から評定することを目的とする。本実験では, 情動ス トレスとしてドライバに時間制限を設けた疑似運転課題を 与え, 生理量を脳波, 心拍, 顔面熱画像から計測し, 同時 に取得する主観量, 蛇行量や操舵角等の運転行動量との比 較検討を行うことにより，時間的圧迫状況下での自動車運
転時のドライバの生理心理状態を評価する。

\section{2. 実験方法}

〈2・1〉実験システム図 1 に温度取得領域を示す。図 2 に計測システムを示す。室温は $25 \pm 1.0$ 度, 照度は $200 \mathrm{~lx}$, 室内は無風とする。被験者は実物の自動車用シートに着座 する。操作部として輪形操舵ハンドルを設置する。被験者 前方には 80 インチのプロジェクト・スクリーンを配置し, 擬似運転課題の制御用 PCに接続された液晶プロジェクタ を介して, 擬似運転課題を映写する。赤外線サーモグラフィ 装置（NEC 三栄社製 TH3102）は被験者の鼻尖から水平距 離 $1.0 \mathrm{~m}$ の位置に配置する。本装置の熱画像サイズは 255 $\times 239$ pixel, 温度分解能は $0.08{ }^{\circ} \mathrm{C}$, 皮膚放射率は $\varepsilon=0.98$ とし, 測定された顔面熱画像は専用 PCにサンプリング周 波数 $0.5[\mathrm{~Hz}]$ で記録する。脳波の導出電極は国際 10-20 法 に基づく 3 点 $(\mathrm{F} 3, \mathrm{~F} 4, \mathrm{Fz})$ とし, 電極ボックスを介して 脳波計（日本光電製 EEG-2110）に接続する。また，心電 図測定用の電極は, 左鎖骨下 $(\mathrm{N})$, 右鎖骨下 $(-)$, および, 左前最下助骨 (+) の 3 点に装着する (I I 誘導近似)。心電 図出力はへッドサイドモニタ（日本光電社製 BSM-3201） を介して脳波計の DC 入力部に接続する。脳波計のサンプ リング周波数は $500[\mathrm{~Hz}]$ とする。被験者前方には顔表情撮

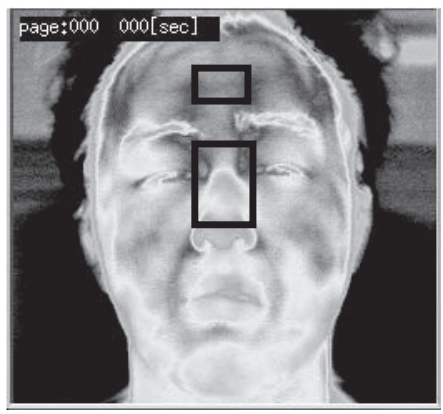

困 1 温度取得領域

Fig. 1. Acquisition area of temperature

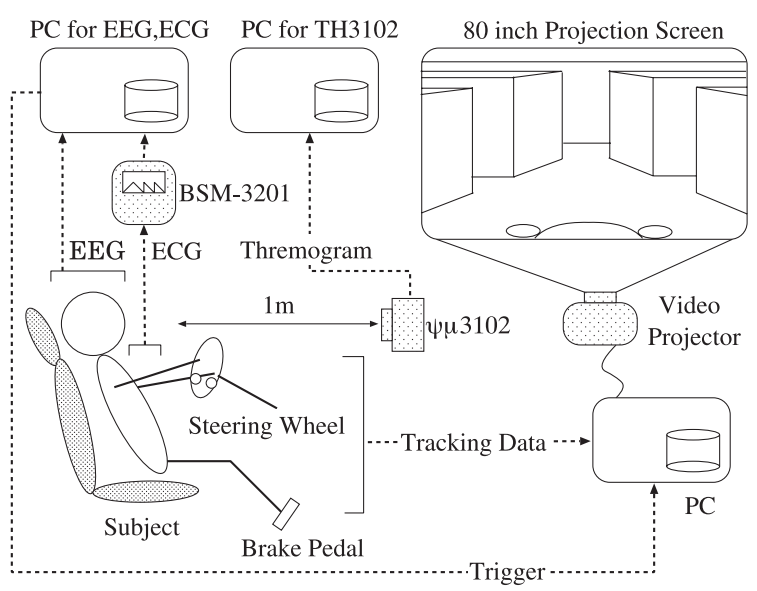

図 2 計測システム

Fig. 2. Measurement system. 
影用と俯瞰撮影用の 2 台の CCD カメラを設置する。2つ の CCD カメラ画像と顔面熱画像は, 顔面分割装置 (朋栄 製 MV-40F) により LCD ディスプレイ装置に表示すると 共にHDD レコーダにて記録する。

\section{$\langle 2 \cdot 2\rangle \quad$ 課題と評価}

$\langle 2 \cdot 2 \cdot 1\rangle$ 擬似運転課題擬似運転課題は, 簡易シミュ レータによる自動車が障害物に衝突しないように目的地ま で移動する作業とする。自動車が走行するフィールドは被 験者が建物や道を熟知している青山学院大学相模原キャン パスをモデルとした。被験者は操作ハンドルとペダルを操 作して自動車を移動させる。評価項目は障害物との衝突回 数と目的地までの到達時間, 操舵量, 蛇行量とする。

$\langle 2 \cdot 2 \cdot 2\rangle$ 副次課題副次課題として, 目的地までの 移動に要する時間に制限時間を設け，時間的圧迫を与える。 時間的圧迫の難易度は以下の四通りである。

No time pressure: 制限時間なし

Easy:

Intermediate:

制限時間=平均到着時間 $+10 \mathrm{sec}$

Difficult: 制限時間 $=$ 平均到着時間 制限時間=平均到着時間 $-10 \mathrm{sec}$

平均到着時間は，予備実験による被験者固有の到着時間の 平均より求めた。また，複数の被験者に可能なかぎり急い で運転してもらった場合，その到着時間が平均到着時間の 約ー $10 \mathrm{sec}$ であったため，Difficult の制限時間を上記のよ うに決定した。また，平均到着時間が時間的圧迫である制 限時間の中心になるようにEasy の制限時間を上記のよう に決定した。

$\langle\mathbf{2} \cdot \mathbf{3}\rangle$ 測定手順図 3 に計測のスケジュール, 図 4 に撮影画像を示す。測定環境への慣れを考慮し被験者には

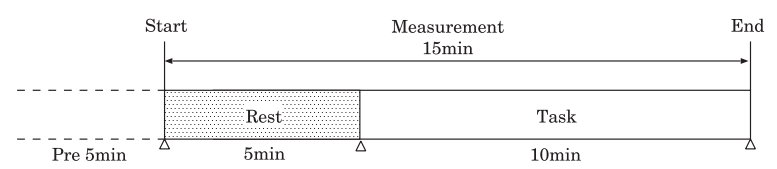

図 3 タスクと計測のスケジュール

Fig. 3. Schedule of task and measurement.

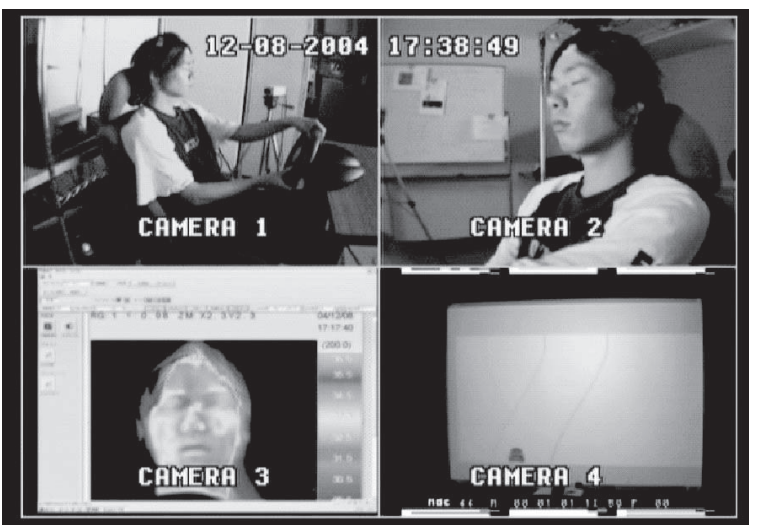

図 4 撮影画像

Fig. 4. Photography image
座位開眼状態で 15 分間安静にさせ，測定が円滑に正しく 行われるように実験の趣旨や測定手順などを詳しく説明す る。安静時間終了 5 分前から各種測定を開始し, 安静時間終 了と同時に擬似運転課題及び副次課題を行う。課題終了後 に被験者は実験に関する主観的心理量をVisual Analogue Scale(VAS) アンケートに記入する。また，擬似運転課題 に十分慣れさせる為, 擬似運転課題のみの課題を日にちを 変えて 5 回行わせる。その後, 各難易度の副次課題を加え た課題を Easy, intermediate, Difficult の順に日にちを変 えて行う。被験者は健常成人 6 名である。

\section{3. 測定項目}

$\langle\mathbf{3 \cdot 1}\rangle$ 生 理 量 運転中のドライバの顔面熱画像に よる心理生理状態評定を目的とし, 測定されたその他の各 種生理指標に関するこれまでの研究例を参考に, メンタル ワークロードの変動を評価する。以下に各生理指標につい ての評価法を示す。

顔面熱画像： 鼻部皮膚温度と前額部皮膚温度の差分温度 を $\mathrm{T}(\mathrm{t})$ と定義する。 $\mathrm{t}$ は夕スク開始からの時刻とする。本 実験では夕スク前安静時間 $60 \mathrm{sec}$ の鼻部額部差分温度の 平均值 $\mathrm{T}(\mathrm{t} 0)$ とタスク中最も変位の大きい時の温度 $\mathrm{T}(\mathrm{t})$ との差分温度 $\mathrm{T}(\mathrm{t} 0)-\mathrm{T}(\mathrm{t})$ を最大温度変位 $\Delta T_{\max }$ (図 5) と定義し，これに注目する。

脳波: 測定された脳波に対して周波数解析を行い，安静 時間を基準とした $\alpha$ 波パワー $(8 \sim 13[\mathrm{~Hz}])$ の变化率に注 目する。脳活動の活性に伴って変化し，メンタルワーク ロードの増減により変動すると考えられる。

心拍: $\quad \mathrm{R}$ 波と $\mathrm{R}$ 波の間隔 $(\mathrm{RRI})$ を取得し，安静時の平 均 RRI 変動係数を基準としたタスク時の平均 RRI 変動 係数の変化率で評価する。心臓交感神経と心臓副交感神 経の拮抗支配を受けており，ストレス時には交感神経が 優位になり，RRI が短くなる。また，夕スク時は安静時 よりも変動しないことが予想される。

$\langle 3 \cdot 2\rangle$ 心 理 量 心理量は主観的な個人差が存在し, 絶対的に定量化するのは困難である。しかし，VAS は，対 をなす語句を両端に配置したスケール上のマーク位置によ り，主観的心理量を測定することが可能となる。スケール の長さに対するマーク位置の長さを百分率で表し, 心理量

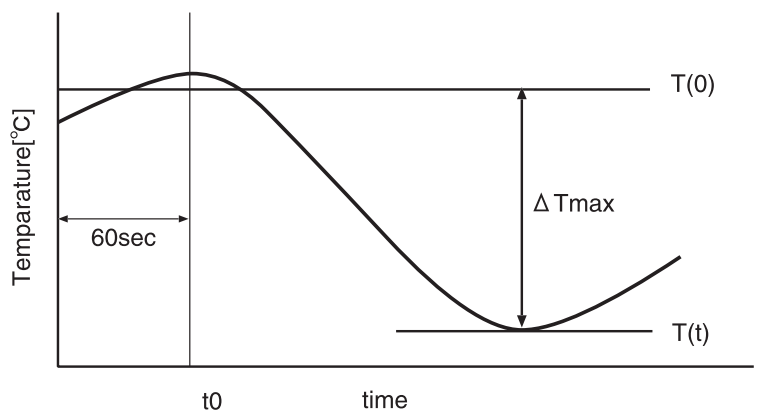

図 5 最大温度変位

Fig. 5. Strength of vibration-voltage (Non brake) 
の評価值とする。評価項目は

（1）「運転の難度」(Difficulty of task)

(2)「運転に対する集中度」(Concentration)

(3)「焦燥度」(fretfulness)

（4）「実験に対する意欲」(Motivation) について測定する。值が高いほど（1）では難しい，(2) で はより運転に集中し（3）ではより焦燥に駆られ，(4) では 継続意欲が増加したとする。

\section{4. 結果と考察}

図 6 に，時間的圧迫状況下におけるドライバの皮膚温度 変化の一例を示す。夕スク開始後, 時間的圧迫の難易度に関 係なく徐々に温度が低下している。これは，他の被験者にお いても同様の結果が見られている。このことから，運転を するという行為が情動ストレスとなり，自律神経系へ影響 を与えており，また，疑似運転課題が時間的圧迫よりも強い 情動ストレスであると言える。疑似運転課題開始 150 [sec] 後付近から No Time pressure の温度降下が緩やかになり， また，その他のタスクも400[sec] 付近から徐々に差が開い ている。このことから，この被験者は 400[sec] 付近までに 疑似運転課題に慣れ始めたため, Difficult と比べ時間的圧 迫による情動ストレスの少ない No Time Presure, Easy， Intermidiate は温度降下が緩やかになっていると推測され る。またDifficultの場合, 被験者は時間的圧迫による情動 ストレスを感じ続けているため，400[sec] を過ぎても温度 降下が持続しているものと推測できる。

図 7 に, No Time Pressure を基準とした各タスクにおけ る最大温度变位の変化率を示す。最大温度変位では被験者 間の比較ができないため, No Time pressure を基準とする 変化率を用いた。No Time pressure, Easy, Intermidiate の変化率は，被験者によって様々である。Intermidiate は 制限時間を平均到着時間としているために, 時間的圧迫に よる情動ストレスが少なく，また，Easyに関しては，制限 時間を平均到着時間 $+10[\mathrm{sec}]$ としているため, 情動ストレ スはほとんどなかったものと推測できる。 Intermidiate と Difficult を比較すると， 6 人中 4 人の変化率が上がってい る。これは，時間的圧迫が大きくなると情動ストレスも大 きくなってくるという傾向があることを示している。図 8 に，各タスクにおける焦燥度を示す。図 7 で, Intermidiate に比べ Difficult の変化率が上がっていた 4 人中 3 人が Intermidiate に比べDifficult の焦燥度も上がっている。ま た図 7 で, Intermidiate に比べ Difficult の変化率が下がっ ていた 2 人については, Intermidiate に比べ Difficult の 焦燥度もさがっている。 $\Delta \operatorname{Tmax}$ と焦燥度の Intermidiate と Difficult の相関係数が 0.72 となっており，高相関が得 られている。このことから，運転中の時間的圧迫による情 動ストレスを鼻部皮膚温の温度変動によって計測する場合, Difficult のような情動ストレスに大きな影響を与える場合 の生理心理状態の評価が可能であることが分かった。図 9 に，各タスクにおける衝突回数を示す。 6 人中 4 人が No

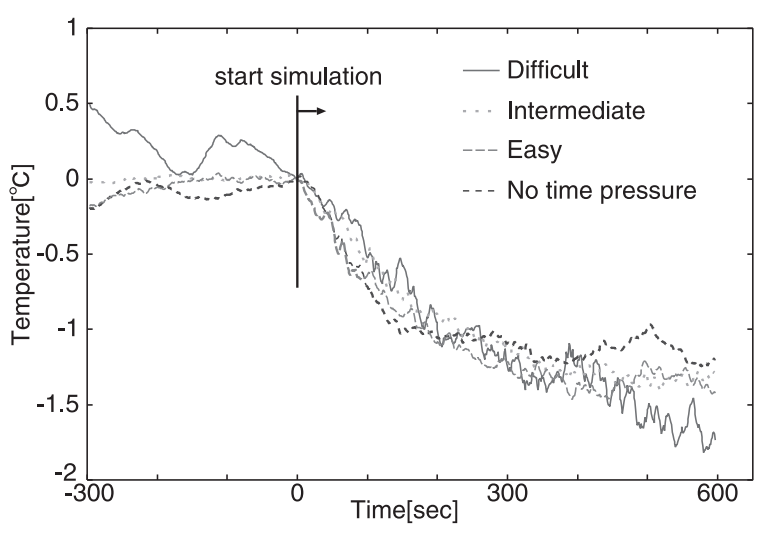

図 6 時間的圧迫状況下におけるドライバの皮膚 温度変化

Fig. 6. Driver's skin temperature change on time pressure stiuation

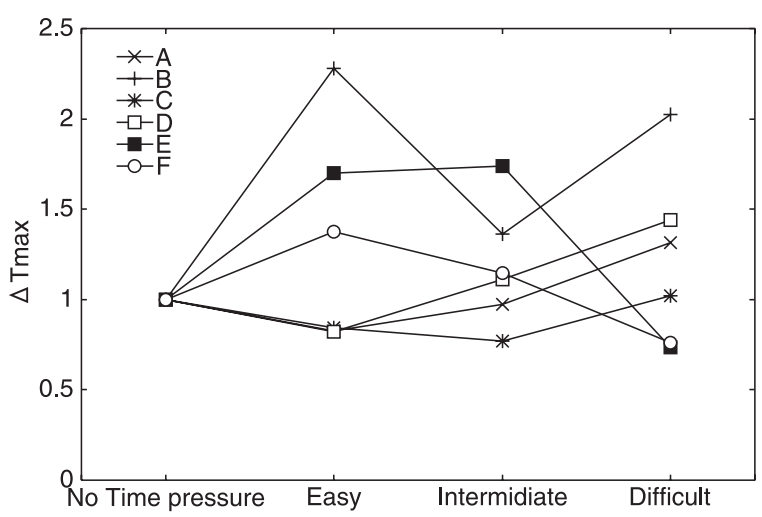

図 $7 \Delta \operatorname{Tmax}$ の変化率

Fig. 7. A $\Delta$ Tmax rate of change

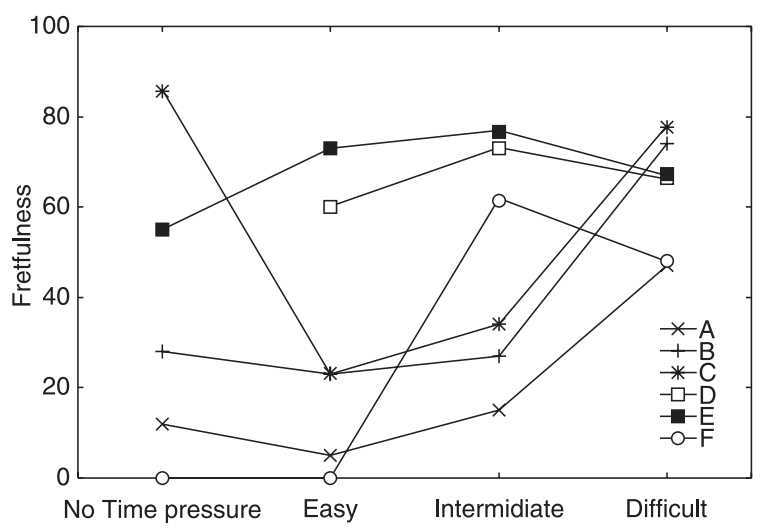

図 8 各夕スクにおける焦燥度

Fig. 8. Fretfulness in each task

Time pressure, Easy, Intermidiate と比べDifficult の衝 突回数が上がっている。また, Difficult の変化率が上がっ ていた 4 人中 3 人が Intermidiate に比べ Difficult の衝突 回数も上がっている。 $\Delta$ max と衝突回数の Intermidiate と Difficult の相関係数 0.49 となっており，相関が見られ なかった。困 10 に，安静時間を基準とした各夕スクにお 


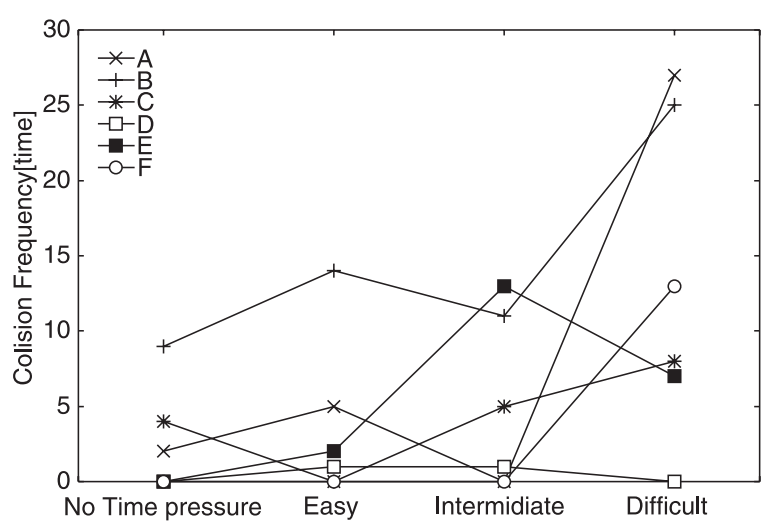

図 9 各夕スクにおける衝突回数

Fig. 9. Collision frequency in each task

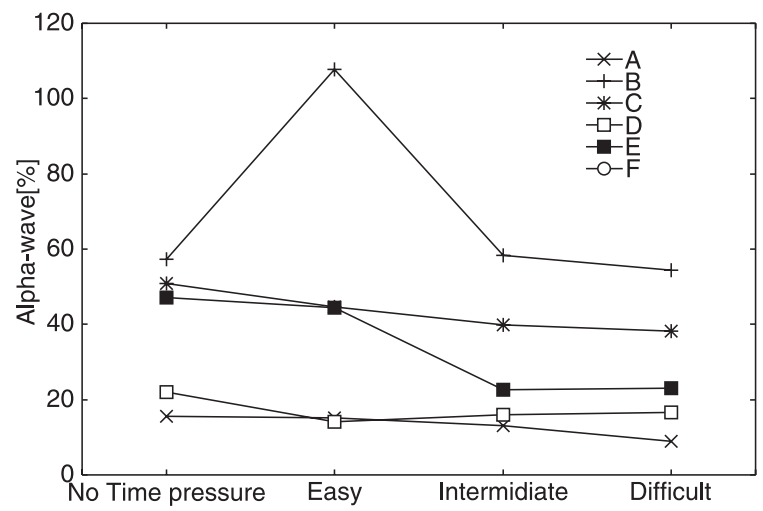

図 10 各タスクにおける $\alpha$ 波パワーの変化率

Fig. 10. An alpha wave power rate of change in each task

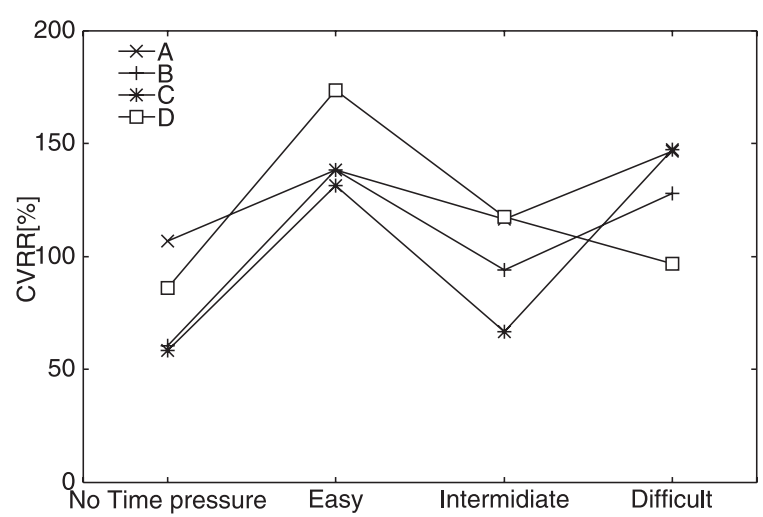

図 11 各夕スクにおける R-R 間隔変動係数 (CVRR)の変化率

Fig. 11. A coefficient of variation at R-R interval of change in each task

ける $\alpha$ 波パワーの変動率を示す。全ての被験者に対して No Time pressure, Easy, Intermidiate と Difficult を比較す ると， $\alpha$ 波パワーに大差はなかった。図 11 に，R-R 間隔 変動係数 $(\mathrm{CVRR})$ の変化率を示す。どの被験者も時間的 圧迫を与えた方が RRI が短くなり, CVRRの変化率が上 がっているが，難易度による違いは見られなかった。副次課
題で，難易度を 4 通りの時間的圧迫を与えたが，No Time pressure, Easy, Intermediateの 3 通りについて生理指標 は, 被験者間で違いはあるものの, 同一被験者では大差は なかった。

\section{5. まとめ}

本稿では擬似運転課題のみと擬似運転課題中における副 次課題提示時について顔面熱画像 - 心拍 - 脳波などの生理 量, VAS アンケートによる主観的心理量, 衝突回数などの 運転行動量の評価実験を試みた。結果，時間的圧迫を与え ることにより鼻部皮膚温度と前額部皮膚温度の差分温度の 時空間変動に変化が現れた。時間的圧迫の難易度を高くす ると，最大温度変位も大きくなったことから，時間的圧迫 によるストレスが自律神経系活動に影響を及ぼしたことが 分かった。また, 最大温度変位 $\Delta T \max$ の変化率と焦燥度 に高い相関がみられた。以上から，今実験での運転中のド ライバの時間的圧迫や衝突による影響において, 顔面熱画 像による生理量の評価の有効性が示唆された。

(平成 19 年 1 月 26 日受付, 平成 19 年 6 月 15 日再受付)

\section{文献}

（1）平成 17 年中の道路交通事故の状況，交通安全白書

（2）日本ヒューマンファクター研究所，http://www.jihf.com/

（3）公共交通に係るヒューマンエラー事故防止対策検討委員会, 最終とり まとめ, http://www.mlit.go.jp/kisha/kisha06/01/010426/01. pdf

（4）野澤昭雄・田中久弥・井出英人：「顔面熱画像解析に基づくドライ バーの生理計測」，計測研究会資料，IM-04-64 (2004)

(5) Y. Nishio and M. Suzuki: "Evaluation of Human Arousal Levels through Physiological Responses", OMRON TECHNICS, Vol.38, No.2, pp.184-190 (1998) (in Japanese) 西尾恭幸・鈴木正幸:「生体情報による覚醒度評価技術一自動車運転中 の居眠り判定法と判定システムについて」, OMRON TECHNICS, Vol.38, No.2, pp.184-190 (1998)

(6) T. Asao, J. Ishimura, T. Wada, and K. Tsukamoto: "Influence of Conversational Contents on Driving Behaviors", Transaction of Society of Automotive Engineers of Japan, Vol.35, No.2, pp.205-210 (2004) (in Japanese) 朝尾隆文・石村 潤・和田隆広・塚本一義:「会話内容が運転行動に及ほ す影響について」, 自動車技術会論文集, Vol.25, No.2, pp.205-210 (2004)

( 7 ) Y. Ueno, Y. Kuriyagawa, and I. Kageyama: "Study on a Driver Strain-State Estimating Method Using Facial Temperature at the Obstacle Avoidance", Proceedings of Human Interface 2003, Vol.2003, pp.787-790 (2003) (in Japanese) 上野由歌・栗谷川幸代·景山一郎：「顔面温度を用いた障害物回避時 の緊張状態推定に関する研究」, ヒューマン・インタフェース・シン ポジウム論文集，Vol.2003,pp.787-790 (2003)

（8）水川英明・町田信夫 ·伊藤彰亮：「高速走行時における運転者の心身 反応の計測」, 日本大学理工学部学術講演会講演論文集, Vol.45th, pp.322-323 (2001)

（9）高江康彦 · 飭取成明 - 渡辺隆行 - 久芳憲治 ·吉次律俊 - 三宅晋司 : 「運転時の短期記憶課題による生理反応への影響」, 自動車技術会学 術講演会前刷集, No.51-04, pp.21-24 (2004)

(10) A. Nozawa, H. Mizawa, T. Mizuno, H. Tanaka, and H. Ide: "Evaluation of the Driver's Mental Workload by Conversational Form based on Facial Skin Thermal Image Analysis", IEEJ Trans. SM, Vol.126, No.8, pp.412-418 (2006-8) (in Japanese)

野澤昭雄 · 三澤裕樹 · 水野統太 - 田中久弥 - 井出英人 : 「顔面熱画 像解析による会話形態に関する運転者のメンタルワークロードの評 価」, 電学論 E, 126, 8, pp.412-418 (2006-8)

(11) R. Sakamoto, A. Nozawa, H. Tanaka, T. Mizuno, and H. Ide: 
"Evaluation of the Driver's Temporary Arousal Level by Facial Skin Thermogram -Effect of Surrounding Temperature and Wind on the Thermogram-", IEEJ Trans. EIS, Vol.126, No.7, pp.804-809 (2006-7) (in Japanese)

坂本 涼 - 野澤昭雄 - 田中久弥・水野統太・井出英人:「顔面熱画 像によるドライバの覚醒評価-周辺温度と風量の影響」, 電学論 $\mathrm{E}$, 126, 7, pp.804-809 (2006-7)

(12) K. Nagumo, H. Zenju, A. Nozawa, H. Ide, and H. Tanaka: "Evaluation of Temporary Arousal Level using Thermogram Images", 19th Sensing Forum, Vol.2, pp.95-98 (2002) (in Japanese)

南雲和之·善住秀行 · 野澤昭雄 - 井出英人, 田中久弥：「顔面熱画 像を用いた一過性覚醒評価」，第 19 回センシングフォーラム資料， Vol.2, pp.95-98(2002)

(13) S. Tomono, A. Nozawa, and H. Ide: "Evaluation of the Fight or Flight Reaction by Facial Skin Temperature", The Paper of Technical Meeting on Instruction and Measurement, IEE Japan IM-04-27, pp.35-38 (2004) (in Japanese) 伴野聡・野澤昭雄・井出英人：「顔面皮膚温による闘争・逃避反応の 評価」, 電学計測研資, IM-04-27, pp.35-38 (2004)

（14）山田富美雄：「医療行動科学のためのミニマム・サイコロジー」, 北 大路
野 澤 昭 雄

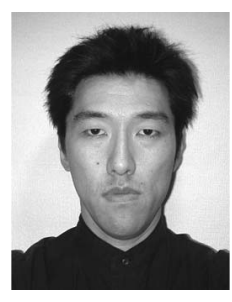

（正員） 1997 年青山学院大学大学院理工学部研 究科博士前期課程修了 (電気電子工学専攻)。大日 本印刷 (株), 青山学院大学理工学部電気電子工学 科助手を経て現在, 明星大学電気電子システム工 学科講師。主に生体計測, ロボティクス, 感性工 学に関する研究に従事。博士 (工学)。電子情報通 信学会, 日本感性工学会, 日本サーモロジー学会 会員。
田中久弥

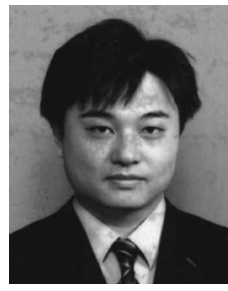

(正員) 1997 年工学院大学大学院工学研究科修 士課程修了 (情報工学専攻)。生体情報工学の研究 に従事, 青山学院大学理工学部電気電子工学科助 手, 広島市立大学情報科学部情報数理学科講師を 経て現在, 工学院大学情報科学研究教育センター 講師。工博。電子情報通信学会。日本 ME 学会 会員。

井出 英 人 (正員) 1970 年工学院大学大学院工学研究科修

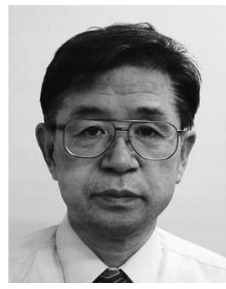
士課程修了 (電気工学専攻)。1985 年 UCLA 応 用科学科客員研究員。1986 年 UCLA 脳研究所客 員教授。感覚の計測, 感覚代行の研究に従事。青 山学院大学理工学部講師, 助教授を経て現在, 同 教授。1996 年より 2002 年まで同学部長。工博。 日本ロボット学会, 計測自動制御学会会員。日本 生理学会論文賞。電気学会論文賞。 